\title{
Global Learning Using Biology PBL: A Texas-China Collaboration in Middle Grade Genetics
}

\author{
Blair O'Connor and Rebecca Hite
}

Texas Tech University, Texas

\begin{abstract}
Twenty-first century and global skills are generally described as competencies for communication and problem solving. Additionally, these skills involve developing the ability to view content-specific issues through a multicultural perspective. Preparing K-12 students for STEM careers in an ever-changing workplace means they must have opportunities to concurrently acquire skills in twenty-first century and global learning. Additionally, the professional biology community has called for advancing middle grades students' knowledge of complex scientific phenomena using novel pedagogies like Project-Based Learning (PBL).

Thus, middle grade educators are now tasked to design classroom opportunities for STEM-focused PBL using global interaction to hone global and twenty-first century skills, while developing students' content knowledge. In this article, we provide an account of a classroom-centered project that paired middle school students in Texas with Chinese peers to collaborate on a biology-based PBL activity on the topic of genetics. During the seven-day unit on heredity, the goal was to utilize global collaboration in STEM to achieve learning objectives in the biology curriculum (understanding inheritance and differentiating between dominant and recessive traits), while embedding skills that foster global competency and twenty-first century skills. The context, planning, and outcomes of the global collaboration are discussed, as well as recommendations for future global collaborative STEM initiatives in middle school.
\end{abstract}

Keywords: Twenty-first century skills, Genetics; Global Competency, Global Collaboration, Heredity; Project Based Learning, STEM Education

\section{GLOBAL COLLABORATION IN TWENTY- FIRST CENTURY LEARNING AND SCIENCE EDUCATION}

A ccording to Greenhill (2010), there are three reasons why the United States needs educational reform: 1) close achievement gaps, 2) address the new educational demands from our changing economy, and 3) prepare students with the skills necessary to work in a global job market. This response to reform requires students to grasp global or twenty-first century skills such as creativity, critical thinking, problem solving, communication, and collaboration (Partnership for twenty-first century Learning, 2016).

The call for these global skills has uniquely challenged the education community where global collaboration has been historically viewed as an addon to the curriculum (Tye, 2003), instead of a pedagogical approach (Bell, 2010; Saavedra \& Opfer, 2012). According to Lindsay and Davis (2013), "Global competition for jobs means that today's students must not only be well-educated, creative problem solvers, but also be equipped to collaborate globally" (p. 3). Yet, students are afforded few opportunities to collaborate with their international peers, due to challenges in cross-cultural communication (Shih \& Cifuentes, 2003), minimal or non-existent pre-service teacher preparation in global classroom activities (Neal, Mullins, Reynolds, \& Angle, 2013), and curricular pressures of mandatory testing, including time constraints and mandated curricula (Au, 2007). Educators need tangible strategies in which they can provide their students opportunities to collaborate globally, through the use of internet-based technologies, with engaging content that also meets state standards and assessment requirements.

\section{TWENTY-FIRST CENTURY LEARNING USING PROJECT BASED LEARNING (PBL)}

According to the Buck Institute (n.d.), the twentyfirst century workplace requires more than basic knowledge and skills. They propose students work collaboratively on activities and projects, which enable them to build confidence and develop skills such as problem solving, communicating, leadership, and accountability (Greenhill, 2010). 
Project Based Learning (PBL) has emerged as a novel pedagogical practice in which students are tasked with long-term projects investigating complex real-world problems, questions, or challenges to co-construct knowledge, while also building interpersonal, twenty-first century skills (Krajcik \& Blumenfeld, 2006; Larmer \& Mergendoller, 2010).

An inherently student-centered model, PBL-derived research plans and products are student designed and produced. PBL stands apart from other instructional designs in its authenticity, as well as the ability to allow students to learn and work autonomously with teacher facilitation (Thomas, 2000). By providing students opportunities to address real-world problems, their learning is more relevant (Thomas, 2000) and engaging (Ahlfeldt, Mehta, \& Sellnow, 2005). Research by Morrison, McDuffie, and French (2015) recommended leveraging $\mathrm{PBL}$ as a pedagogical strategy for developing problem solving via authentic inquiry , which is vital to the new world economy. Using PBL with STEM may be a useful practice for fostering the "STEM fields [which] propelled the United States to the forefront of an innovation-based global economy" (National Research Council, 2011, p. 4).

\section{PBL IN MIDDLE GRADES SCIENCE EDUCATION}

PBL has shown great promise in STEM education; a study by Han, Capraro, and Capraro (2014) found this pedagogy benefitted lower performing students in mathematics scores, especially students who were ethnic minorities and low socio-economic students (SES). Lou, Shih, Diez, and Tseng (2011) found that students increased their STEM knowledge, and learned how to apply STEM in real world contexts, leading to more positive attitudes towards STEM careers.

Other research has shown that developing positive attitudes toward the sciences improves interest and identity in the sciences (Hayden, Ouyang, Scinski, Olszewski, \& Bielefeldt, 2011). The research literature suggests that developing a robust science identity within students is critical to engagement and persistence within STEM careers (Perez, Cromley, \& Kaplan, 2014), especially among those in marginalized populations (Chemers, Zurbriggen, Syed, Goza, \& Bearman, 2011), and with students in the middle grades (Carlone, Scott, \& Lowder, 2014). Therefore, the social focus and collaborative nature of PBL may be a strategy to enhance science identity development (Calabrese-Barton et al., 2013).

\section{A CASE OF GLOBAL COLLABORATION: A MIDDLE SCHOOL TEXAS-CHINA PBL PROJECT ON GENETICS}

Participating Schools. Little Middle School (LMS, pseudonym) has approximately 900 students in grades six through eight in Texas. It is a Title I school; with $85 \%$ of students categorized as economically disadvantaged and $75 \%$ are Hispanic. The global partner, was Southern Middle School (SMS, pseudonym), in southern China near Hong Kong. The cooperating teacher at SMS, X.H. (pseudonym), taught five eighth grade classes, all of which have 40 or more students. X.H.'s students are Asian and mostly from wealthy families, whose parents come from different provinces, as this area is largely made up of migrants.

Participating Teachers. The teacher-partner at LMS R.B. (pseudonym) has taught seventh grade science for 15 years and coaches girls' athletics. She taught four classes totaling 100 seventh grade students all of which participated in the project. The Chinese teacher X.H. has taught biology for one year at SMS in China. She taught eighth grade classes made up of about 240 students, 55 of which participated in the project.

Participating Students. LMS students are categorized as economically disadvantaged, with few or limited opportunities to access the world outside of their neighborhood. A stereotypical viewpoint of low-SES students like the LMS context is that they are of poorer academic abilities (Spencer \& Castano, 2007), lower academic achievement (Perry \& McConney, 2010), have a mistrust of different cultures (Glazer \& Moynihan, 1970), and are less aware of global issues (Ferreira, 2011).

In contrast, SMS was a private urban school, where many of the students come from wealthy families. Students who come from similar middle to upperclass families often have advantages in developing a more robust worldview, due to the economic advantages and multicultural opportunities their families can provide (Barton, 2001; Crawford \& Meyer, 2011).

Relationship to the Standards. In Texas, the Texas Essential Knowledge and Skills (TEKS) mandate that students are able to define heredity and recognize that inherited traits are passed from parents to 
offspring (TEKS 7.14 A and C). As supporting standards, students may be tested on this content on the yearly State of Texas Assessments of Academic Readiness (STAAR) test (STAARTM, 2013).

SMS follows the National curriculum or Compulsory Education Biology Curriculum Standards. According to Gardner, Enshan, and Fuchs (n.d.), Chinese students begin learning about biology in ten major topic areas, including genetics, in the seventh grade. These studies narrow to three areas in high school, one of which is genetics and evolution. In middle school, Chinese students gain a basic understanding of heredity, focusing on differences between dominant and recessive traits. This project extended that learning by including the concepts of genotypes and phenotypes, which are typically not learned until high school (Gardner et al., n.d.).

Global PBL on Heredity. Due to limitations in exchange media, the students were not able to interact directly. The students gathered the data and discussion points to share with their Chinese partners and interaction occurred through the teachers via email and chat apps. The unit was structured using the 5E model, a teaching method consisting of five sequential components: engaging student interest, exploration using inquiry, student driven explanation of phenomena, extending student understanding, and evaluation of learning (Bybee et al., 2006). This model was selected based upon its successful use in science education and development of twenty-first century skills (Bybee, 2009). The following outlines the progression of the global PBL collaboration by sequencing the heredity unit through a description of the students' activities.

Engage (Day 1, 10-15 minutes). To engage the lesson, R.B.'s students completed a card sort, in small groups, comparing examples and nonexamples of inherited traits (see Appendix A). Once the cards were sorted, the students discussed where each example/non-example went and why.

Explore (Day 1, 30 minutes). Following the card sort, students worked in groups to create a diagram of traits noted in their own classroom such as eye, skin, or hair color, eye shape, height, etc. Once the diagrams were complete, students completed a gallery walk around the room to compare with their classmates.

Explain (Day 2 and 3, 30-45 minutes each day). Students worked in groups to research definitions of heredity, inherited traits, dominant traits and recessive traits followed by direct instruction to clarify, provide examples of, and address misconceptions regarding these terms.

Elaborate (Day 4-6, at home and in the classroom). The Chinese partners proceeded in a similar manner. X.H. taught eighth graders who have already had lessons on heredity in the seventh grade, so the beginning mostly consisted of review. However, her students had not learned about genotypes, so she infused this into the review prior to completing the Elaborate component. Students conducted interviews with their family members to determine inherited traits in their family lineage (see Appendix B) and compared dominant traits among the different participating classrooms. From this process, the students made some curious discoveries such as the homogeneity of traits of their Chinese partners versus the wide variety of traits found in their own classroom.

Evaluate (Day 7, 45 minutes). The project ended with a survey to gauge student knowledge and understanding of genetics after the global collaboration (see Appendix C). The survey was followed up with driving questions, which served to pique students' interest, as well as extend their thinking on a national and global scale. For example, are the dominant traits on our campus indicative of dominant traits in other parts of [our town]? How about across Texas? The U.S.? What traits do you think are dominant in [their town]? What about across China? The World?

Evaluation and Assessment. Other than content knowledge, an expectation of the PBL was for students to address the misconception that stereotypes are not based on genetic traits, but are built from the perceptions of society. Global science education is about students participating in traditional science, and also includes students making connections to society (Barton, 2000). When studying heredity, students often question trait inheritance when offspring do not look like their parents (Visscher, Hill, \& Wray, 2008). Students could reconcile genetic similarities and differences with their collected data and peer communication.

\section{DISCUSSION}


Overall, this global collaboration was a success in that the students successfully learned the content and could apply that content to a larger, global scale. Not only did students become proficient in their ability to identify dominant and recessive traits, as well as their inheritance in offspring, but they were also to hold discussions and debates regarding that inheritance. On recent district benchmarks, students who participated in the global PBL had an $85 \%$ pass rate on the standard specific to this project compared to non-participating students $169 \%$ mastery). Evidence for students extending their learning was based upon their individual and groupderived questions for further exploration; students asked questions about the role that race plays in genetic variation, and geographical impacts of genetic variation.

Hence, they had a unique exchange on questions of the commonality of traits between groups of students, citing their geographic and racial separation. LMS has a large English Language Learner (ELL) population; in order to help develop global competencies in changing student demographics, students need opportunities to embrace their cultural perspectives, learn how to share these with the world, and develop empathy for other cultures to be truly competitive in the global marketplace (Greenhill, 2010). By collecting and sharing their own data, the global PBL afforded them the opportunity to make authentic connections with the content, making the learning of even complex topics relevant to them (Thomas, 2000).

Not only did these questions allow for extended learning in science, but also presented the opportunity for interdisciplinary learning including social studies. When Texan students were looking at the homogeneity of the Chinese students' traits, students at LMS raised questions about the lack of genetic variation due to immigration.

They considered if this were an artifact due to politics or industry; where it may be difficult for foreign businesses to work in China or if immigration is difficult due to natural boundaries? These questions not only aligned with several middle school Texas Social Studies standards but also demonstrated growth towards becoming a globally competent person, possessing both multicultural awareness and a respect for diversity (Atwater, 2010).

\section{CONCLUSION}

In a study by Camicia and Zhu (2012), they discuss the need for global education to teach students about seeing issues from multiple perspectives so they may recognize their roles on a global scale, as well as their civic duties in government. While authenticity is imperative to a strong science curriculum (Buck Institute for Education, n.d; Larmer \& Mergendoller, 2010; Thomas, 2000), there is also a need to present content from multiple or global perspectives (Schlein \& Garii, 2011). This study of a global collaboration in middle school biology presented a unique opportunity for students to gain perspective of a different culture, as well as increased perspective of their own, while investigating and sharing data with international peers. Recommended changes based upon this experience concern planning, technology use, and teacher preparation, which has often belied global collaboration projects (Neal et al., 2013).

\section{REFERENCES}

Ahlfeldt, S., Mehta, S., \& Sellnow, T. (2005). Measurement and analysis of student engagement in university classes where varying levels of $\mathrm{PBL}$ instruction methods are in use. Higher Education Research \& Development, 24, 5-20.

Atwater, M. M. (2010). Multicultural science education and curriculum materials. Science Activities, 47(4), 103-108.

Au, W. (2007). High-stakes testing and curricular control: A qualitative metasynthesis. Educational Researcher, 36(5), 258-267.

Barton, A. C. (2001). Science education in urban settings: Seeking new ways of praxis through critical ethnography. Journal of Research in Science Teaching, 38(8), 899917.

Bell, S. (2010). Project-based learning for the $21 \mathrm{st}$ century: Skills for the future. The Clearing House, 83(2), 39-43.

BUCK INSTITUTE FOR EDUCATION. (n.d.). Why Project Based Learning? Retrieved from http://Buck Institute for Education.org/Bybee, R. W. (2009). The BSCS 5E instructional model and 21st century skills. Colorado Springs, CO: BSCS.

Bybee, R. W., Taylor, J. A., Gardner, A., Van Scotter, P., Powell, J. C., Westbrook, A., \& Landes, 
N. (2006). The BSCS 5E instructional model: Origins and effectiveness. Colorado Springs, CO: BSCS.

Calabrese-Barton, A., Kang, H., Tan, E., O'Neill, T. B., Bautista-Guerra, J., \& Brecklin, C. (2013). Crafting a future in science: Tracing middle school girls' identity work over time and space. American Educational Research Journal, 50(1), 37-75.

Camicia, S. P., \& Zhu, J. (2012). Synthesizing multicultural, global, and civic perspectives in the elementary school curriculum and educational research. The Qualitative Report, 17(103), 1-19.

Carlone, H. B., Scott, C. M., \& Lowder, C. (2014). Becoming (less) scientific: A longitudinal study of students' identity work from elementary to middle school science. Journal of Research in Science Teaching, 51(7), 836-869.

Chemers, M. M., Zurbriggen, E. L., Syed, M., Goza, B. K., \& Bearman, S. (2011). The role of efficacy and identity in science career commitment among underrepresented minority students. Journal of Social Issues, 67(3), 469-491.

Crawford, B. A. \& Meyer, X. (2011). Teaching science as a cultural way of knowing: Merging authentic inquiry, nature of science, and multicultural strategies. Cultural Studies of Science Education, 6(3), 525-547.

Lindsay, J. \& Davis, V. (2013). Flattening Classrooms, Engaging Minds: Move to Global Collaboration One Step at a Time. Upper Saddle River, NJ: Pearson Education.

Ferreira, R. (2011). Development of an Instrument to Measure High School Students' Global Awareness and Attitudes: Looking Through the Lens of Social Sciences. FIU Electronic Theses and Dissertations. 373.

Gardner, A., Enshan, L, \& Fuchs, B. (n.d.). Biology Programs in the Peoples Republic of China and the United States. [PowerPoint Slides]. Retrieved from

https://bscs.org/sites/default/files/_legacy/pdf/Resea rch Life \%20Science\%20Standards\%20and \%20HS\%20Textbooks NABT.pptx
Glazer, N., \& Moynihan, D. (1970). Beyond the Melting Pot. Cambridge, MA: The MIT Press.

Greenhill, V. (2010). 21st Century Knowledge and Skills in Educator Preparation. Washington, D.C.: American Association of Colleges for Teacher Education, Partnership for 21st Century Skills. Retrieved from ERIC database (ED519336).

Han, S., Capraro, R., \& Capraro, M. M. (2014). How science, technology, engineering, and mathematics (STEM) project-based learning (PBL) affects high, middle, and low achievers differently: The impact of student factors on achievement. International Journal of Science and Mathematics Education, 13(5), 1089-1113.

Hayden, K., Ouyang, Y., Scinski, L., Olszewski, B., \& Bielefeldt, T. (2011). Increasing student interest and attitudes in STEM: Professional development and activities to engage and inspire learners. Contemporary Issues in Technology and Teacher Education, 11(1), 47-69.

Krajcik, J. S., \& Blumenfeld, P. (2006). Project-based learning. In R. K. Sawyer (Ed.), The Cambridge handbook of the learning sciences (pp. 317-334). New York: Cambridge.

Morrison, J., McDuffie, A. R., \& French, B. (2015). Identifying key components of teaching and learning in a STEM school. School Science and Mathematics, 115, 244-255.

National Research Council. (2011). Successful K-12 STEM Education: Identifying Effective Approaches in Science, Technology, Engineering, and Mathematics. Washington, DC: The National Academies Press.

Neal, G., Mullins, T., Reynolds, A., \& Angle, M. (2013). Global collaboration in teacher education: A case study. Creative Education, 4(9), 533-539.

Partnership for 21st Century Learning. (2016). Framework for 21st Century Learning. Retrieved from 
http://www.p21.org/storage/documents/doc s/P21 framework 0816.pdf

Perez, T., Cromley, J. G., \& Kaplan, A. (2014). The role of identity development, values, and costs in college STEM retention. Journal of Educational Psychology, 106(1), 315-329.

Perry, L. B., \& McConney, A. (2010). Does the SES of the school matter? An examination of socioeconomic status and student achievement using PISA 2003. Teachers College Record, 112(4), 1137-1162.

Saavedra, A. R., \& Opfer, V. D. (2012). Learning 21 st-century skills requires 21 st-century teaching. Phi Delta Kappan, 94(2), 8-13.

Schlein, C., \& Garii, B. (2011). Cross-cultural interpretations of curricular contextual crossings. Issues in Teacher Education, 20(2), 81.

Shih, Y. C. D., \& Cifuentes, L. (2003). Taiwanese intercultural phenomena and issues in a United States-Taiwan telecommunications partnership. Educational Technology Research and Development, 51(3), 82-90.

Spencer, B., \& Castano, E. (2007). Social class is dead. Long live social class! Stereotype threat among low socioeconomic status individuals. Social Justice Research, 20(4), 418-432.

State of Texas Assessments of Academic Readiness (STAARTM) Assessments. (2013). STAAR Standard Setting Technical Report. Retrieved from: tea.texas.gov/WorkArea/DownloadAsset.as $p x ? i d=25769804117$

Texas Education Agency (2017). Test Information At A Glance. Retrieved from http://tea.texas.gov/TxCHSE Test Informati on At A Glance.html

Thomas, J. W. (2000). A review of research on project-based learning. San Rafael, CA: Autodesk Foundation.
Tye, K. A. (2003). Global education as a worldwide movement. Phi Delta Kappan, 85(2), 165168.

Visscher, P. M., Hill, W. G., \& Wray, N. R. (2008). Heritability in the genomics era-concepts and misconceptions. Nature Reviews Genetics, 9(4), 255-66.

\section{ABOUT THE AUTHORS}

Blair O'Connor is a doctoral student in the Global PRiSE Ph.D. Programs at Texas Tech University. Rebecca Hite, a 2010 Kenan Fellow is an assistant professor of Science Education in the STEM Education \& Global PRiSE Ph.D. Programs at Texas Tech University. 


\section{APPENDIX A}

Card Sort of Examples and Non-examples of Inherited Traits

\begin{tabular}{|c|c|}
\hline Inherited Traits Examples & Inherited Traits Non-Examples \\
\hline Eye Color & Good at Math \\
\hline Hair Color & Intelligence \\
\hline Shape of Eyes, Ears, or Nose & Laziness \\
\hline Skin Color & Athleticism \\
\hline Brain Structure & Bad Drivers \\
\hline Migration Patterns & Good Behavior \\
\hline Addiction & Hard Worker \\
\hline Camouflaged Fur, Feathers, or Scales & Favorite Foods \\
\hline
\end{tabular}




\section{APPENDIX B}

Traits Data from X.H.'s and R.B.'s Classroom

\begin{tabular}{|c|c|}
\hline Traits & Number of Students X.H./R.B. \\
\hline \multirow{2}{*}{$\begin{array}{l}\text { Attached ear lobe. (ee) } \\
\text { Unattached earlobe. }\end{array}$} & $35 / 6$ \\
\hline & $20 / 49$ \\
\hline \multirow{2}{*}{$\begin{array}{l}\text { Blue eyes. (bb) } \\
\text { Non blue eyes. }\end{array}$} & $0 / 13$ \\
\hline & $55 / 42$ \\
\hline \multirow{2}{*}{$\begin{array}{l}\text { Widow's peak. } \\
\text { Non widow's peak. (ww) }\end{array}$} & $10 / 15$ \\
\hline & $35 / 40$ \\
\hline \multirow{2}{*}{$\begin{array}{l}\text { Tongue roller. } \\
\text { Non tongue roller. (rr) }\end{array}$} & $37 / 47$ \\
\hline & $18 / 8$ \\
\hline \multirow{2}{*}{$\begin{array}{l}\text { Bent pinkie. } \\
\text { Straight pinkie. (pp) }\end{array}$} & 20/19 \\
\hline & $34 / 36$ \\
\hline \multirow{2}{*}{$\begin{array}{l}\text { Hair on mid joints. } \\
\text { No hair on mid joints. (hh) }\end{array}$} & $12 / 29$ \\
\hline & $43 / 26$ \\
\hline \multirow{2}{*}{$\begin{array}{l}\text { Red hair. (nn) } \\
\text { Any other color of hair. }\end{array}$} & $0 / 3$ \\
\hline & $55 / 52$ \\
\hline \multirow[t]{3}{*}{ Curly hair (CC) Wavy hair (Cc) straight hair (cc) } & $0 / 12$ \\
\hline & $4 / 22$ \\
\hline & $51 / 21$ \\
\hline \multirow[t]{3}{*}{ Cleft chin. (cc) Non cleft chin. } & $0 / 7$ \\
\hline & $55 / 48$ \\
\hline & $41 / 28$ \\
\hline
\end{tabular}




\section{APPENDIX B Cont'd}

Traits Data from X.H.'s and R.B.'s Classroom

\begin{tabular}{|c|c|}
\hline Traits & Number of Students $\quad$ X.H./R.B. \\
\hline \multirow{2}{*}{$\begin{array}{l}\text { Almond eyes. } \\
\text { Round eyes. (aa) }\end{array}$} & $49 / 39$ \\
\hline & $6 / 17$ \\
\hline \multirow{2}{*}{$\begin{array}{l}\text { Eyes straight. } \\
\text { Eyes slanted. (ss) }\end{array}$} & $55 / 50$ \\
\hline & $0 / 5$ \\
\hline \multirow{2}{*}{$\begin{array}{l}\text { Bushy eyebrows. } \\
\text { Fine eyebrows. (bb) }\end{array}$} & $26 / 21$ \\
\hline & $27 / 34$ \\
\hline \multirow{2}{*}{$\begin{array}{l}\text { Connected eyebrow. (cc) } \\
\text { Non-connected eyebrow. }\end{array}$} & $4 / 5$ \\
\hline & $51 / 50$ \\
\hline \multirow{2}{*}{$\begin{array}{l}\text { Freckles. } \\
\text { No freckles. (ff) }\end{array}$} & $5 / 15$ \\
\hline & $50 / 40$ \\
\hline \multirow{2}{*}{$\begin{array}{l}\text { Dimples. } \\
\text { No dimples. (dd) }\end{array}$} & $13 / 27$ \\
\hline & $41 / 28$ \\
\hline \multirow{2}{*}{$\begin{array}{l}\text { Hitchhiker's thumb. (hh) } \\
\text { Non hitchhiker's thumb. }\end{array}$} & $34 / 32$ \\
\hline & $21 / 23$ \\
\hline \multirow{2}{*}{$\begin{array}{l}\text { Cross right thumb over left(tt) } \\
\text { Cross left thumb over right. }\end{array}$} & $33 / 29$ \\
\hline & $21 / 26$ \\
\hline \multirow{2}{*}{$\begin{array}{l}\text { Right handed. } \\
\text { Left handed. (hh) }\end{array}$} & $51 / 50$ \\
\hline & $4 / 5$ \\
\hline
\end{tabular}




\section{APPENDIX C}

Post PBL Survey

1. It is important to be able to communicate science information.

Strongly Agree Agree Neutral Disagree Strongly Disagree

2. All cultures have the same dominant and recessive inherited traits.

Strongly Agree Agree Neutral Disagree Strongly Disagree

3. Inherited traits are passed directly from parent to offspring.

Strongly Agree Agree Neutral Disagree Strongly Disagree

4. All members of a family have the exact same DNA.

Strongly Agree Agree Neutral Disagree Strongly Disagree 